\title{
PRELIMINARY STUDIES OF TWIG-NESTING BEES AND WASPS OF GRAND TETON NATIONAL PARK
}

\author{
F. D. Parker \\ V. J. Tepedino \\ USDA-SEA, AR \\ Bee Biology and Systematics Laboratory \\ Utah State University
}

\section{Objectives}

Our objectives in this study were threefold: to gather information to be used in ongoing biosystematic studies of the bee genera 1) Hoplitis (Megachilidae), and 2) Stelis (Megachilidae), a cleptoparasitic genus of Hoplitis; 3) to inventory twig-nesting bees and wasps found in the Park for purposes of comparison with samples from other, less pristine, locations.

\section{Methods}

Twig-nesting aculeates were sampled by setting out 18 -inch elderberry (Sambucus) twigs with single holes of 3,6 , and $9 \mathrm{~mm} \mathrm{drilled}$ down the center. Two shallow holes (depth 2-3 mm) of the same diameter as the central one were also drilled in each twig along the side, below the depth of the central hole. The undrilled end of the twig was cut to a point and the twig was inserted vertically in the ground to a depth of 1-2 inches. Bees and wasps commonly use these "trap-nests" for nesting purposes.

Trap-nests were set out on 17 June 1980 at three locations: Pacific Creek, Pilgrim Creek, and at the dump. Traps were collected for subsequent laboratory examination on 24 September.

In the laboratory, twigs were opened and data recorded on nest architecture, parasites and predators, and pollen or prey utilization. Live specimens were put in gelatin capsules for storage at $40^{\circ} \mathrm{F}$ over the winter. Specimens will be incubated for final development next spring and identified.

\section{Results}

In most cases, final determinations of the species sampled cannot be made until next year. Thus, at this time it is impossible to associate our information on nest architecture, nest depredators, and food utilization with particular species. However, we can provide a preliminary 
estimate of the number of species encountered by the use of species specific patterns of nest architecture, and we can also offer some comments on general nest utilization.

Most species collected were present at all three sites. In Table 1 is a very tentative estimate of the number of species of nest initiators (depredators excluded) recorded by genus or family. The occurrence of the bee genus Proteriades is of particular interest because of its rarity in Wyoming. The species may be $\underline{P}$. plagiostoma and, if so, this would be the easternmost distribution record for the species and the first for Wyoming.

The diversity of twig-nesting species from these sites in the Tetons is similar to other sites that we have sampled in northeastern Utah (e.g., Logan Canyon, Cache National Forest). Many of the species appear to be the same at both sites. However, the percent utilization of nests is considerably higher in the sample from the Tetons: in the Tetons about $70.0 \%$ of all holes provided (both ends and sides) were utilized for nests (Table 2) whereas samples from Logan Canyon and other sites typically show $40-50 \%$ utilization. Thus, while the diversity of twignesters in the Park does not seem different from other areas, the abundance of individuals appears much higher in the Park.

The abundance of twig-nesting species in the Park may be attributed to the availability of natural nesting sites. Dead snags and fallen, rotting logs which are the natural nesting sites of these species are everywhere abundant and can support large populations. Where dead wood is removed, as in some areas of national forests, nest site availability is reduced and twig-nesting individuals are fewer. 
Table 1. Tentative number of species of nest initiators recorded in trap-nesting studies at three sites in Grand Teton National Park, 1980

\begin{tabular}{|c|c|c|}
\hline & $\begin{array}{c}\text { Genus or Family } \\
\text { Species }\end{array}$ & $\begin{array}{c}\text { Number of } \\
\text { species }\end{array}$ \\
\hline \multirow{8}{*}{ Bees } & Ceratina & 1 \\
\hline & Hylaeus & 1 \\
\hline & Ashmeadiella & 1 \\
\hline & Anthocopa & 1 \\
\hline & Hoplitis & 4 \\
\hline & Megachile & 2 \\
\hline & Osmia & 1 \\
\hline & Proteriades & $\frac{1}{12}$ \\
\hline \multirow{10}{*}{ Wasps } & Ancistrocerus & 1 \\
\hline & Euodynerus & 2 \\
\hline & Leptochilus & 3 \\
\hline & Microdynerus & 1 \\
\hline & Parancistrocerus & 1 \\
\hline & Pemphredon & 1 \\
\hline & Solierella & 1 \\
\hline & Trypoxylon & 1 \\
\hline & Eumen i dae & $\frac{3}{14}$ \\
\hline & Total & 26 \\
\hline
\end{tabular}


Table 2. Nest utilization by twig-nesting wasps and bees at three sites in Grand Teton National Park, 1980.

\begin{tabular}{cccc}
\hline & \multicolumn{3}{c}{ Site } \\
\hline $\begin{array}{c}\text { Number of } \\
\text { nests }\end{array}$ & Dump & $\begin{array}{c}\text { Pilgrim } \\
\text { Creek }\end{array}$ & $\begin{array}{c}\text { Pacific } \\
\text { Creek }\end{array}$ \\
\hline Utilized & 68 & 159 & 156 \\
\hline Unutilized & 25 & 75 & $\frac{51}{207}$ \\
\cline { 2 - 4 } & 93 & 67.9 & 75.4 \\
\hline
\end{tabular}

